\title{
Quorum Quenching Activity of Native Brazilian Fruits
}

\author{
Adeline Conceição Rodrigues (I), Nayara Thais Barbosa \\ Sacramento (I), Elis Regina Silva (I), Michele Correa Bertoldi (I), \\ Uelinton Manoel Pinto (I) \\ (I) UFOP - Universidade Federal de Ouro Preto (Escola de Nutrição. Campus Morro do \\ Cruzeiro. UFOP. Ouro Preto MG. 35400-000)
}

\section{Resumo}

Quorum sensing is a cell density dependent communication mechanism used by bacteria in order to control group behaviors in a manner similar to multi-cellular organisms. QS regulates the expression of several phenotypes ranging from virulence factors to bioluminescence, motility, enzoenzyme production, conjugation, sporulation and biofilm formation. This type of communication relies on the production and detection of signal molecules, known as autoinducers, which accumulate as the cell number increases in the surroundings. Interrupting the quorum sensing circuitry is a promising approach in anti-virulence strategies which could have important implications for food safety and for the medical field. Several works have shown the potential for plant extracts, including medicinal plants and spices, in inhibiting quorum sensing. Grumixama (Eugenia brasiliensis) and pitanga (Eugenia uniflora), two fruits that resemble cherry, belong to the family Myrtaceae, are native from Brazil and rich in phenolic compounds with potential for antioxidant, antimicrobial and quorum quenching activities. This work aimed to evaluate the quorum quenching activity of crude and phenolic extracts obtained from fruits of grumixama and pitanga. Total poliphenols were extracted from pulps of both fruits by using solid phase extraction, quantified by spectrophometry and the polyphenol content expressed as Galic Acid Equivalent. The quorum quenching activity was evaluated by an agar diffusion assay by using equidistant wells and different concentrations of the extracts.

\footnotetext{
Referência:

Adeline Conceição Rodrigues, Nayara Thais Barbosa Sacramento, Elis Regina Silva, Michele Correa Bertoldi, Uelinton Manoel Pinto. Quorum Quenching Activity of Native Brazilian Fruits. In: Anais do 12ㅇ Congresso Latinoamericano de Microbiologia e Higiene de Alimentos - MICROAL 2014 [= Blucher Food Science Proceedings, num.1, vol.1]. São Paulo: Editora Blucher, 2014. 
Chromobacterium violaceum was inoculated in LB agar that was poured into Petri dishes where wells were made and added with aliquots of the extracts or the controls, including sterile distilled water and antibiotics. The inhibition of growth was evaluated as a transparent halo and the inhibition of violacein production, thus quorum sensing inhibition, was observed as colorless halos that presented turbidity. The anti-quorum sensing activity was also evaluated in C. violaceum by measuring the percentage inhibition of violacein production in liquid medium. For this experiment, only subMinimum Inhibitory Concentrations (sub-MIC) were used in order to prevent growth inhibitory effects. The agar diffusion assay showed that crude and phenolic extracts of both fruits presented colorless turbid halos against a purple background, for most of the evaluated concentrations, indicating inhibition of quorum sensing. The results were further confirmed by the violacein production in liquid medium where all extracts at sub-MIC showed between $30 \%$ to $60 \%$ inhibition on pigment production, without affecting bacterial growth. This work shows that two fruits found in Brazil present quorum quenching activity indicating a potential use in the pharmaceutical and food industries. More studies are needed in order to characterize the chemical nature of these compounds.

Palavras-Chave: Brazilian Fruits, Quorum Sensing, Quorum Quenching, Chromobacterium violaceum, Quorum Sensing Inhibition

Agência de Fomento: Conselho Nacional de Desenvolvimento Científico e Tecnológico (CNPq) e Universidade Federal de Ouro Preto 